This is the final peer-reviewed accepted manuscript of:

Moushumi Paul, Gian Marco Baranzoni, Sabrina Albonetti, Jeffrey D. Brewster, Direct, quantitative detection of Listeria monocytogenes in fresh raw whole milk by qPCR, International Dairy Journal, Volume 41, 2015, Pages 46-49

The final published version is available online at: https://doi.org/10.1016/j.idairyj.2014.09.008

Rights / License:

The terms and conditions for the reuse of this version of the manuscript are specified in the publishing policy. For all terms of use and more information see the publisher's website.

This item was downloaded from IRIS Università di Bologna (https://cris.unibo.it/)

When citing, please refer to the published version. 


\title{
Direct, quantitative detection of Listeria monocytogenes in fresh raw whole milk by qPCR
}

\author{
Moushumi Paul a , Gian Marco Baranzoni ${ }^{c}$, Sabrina Albonetti ${ }^{c}$, Jeffrey D. Brewster ${ }^{\text {b }}{ }^{\circ}$ \\ a Dairy and Functional Foods Research Unit, USDA, ARS, NAA, ERRC, 600 East Mermaid Lane, Wyndmoor, PA 19038, USA \\ b Molecular Characterization of Foodborne Pathogens Research Unit, USDA, ARS, NAA, ERRC, 600 East Mermaid Lane, \\ Wyndmoor, PA 19038, USA \\ c Department of Veterinary Medical Science, University of Bologna, Via Tolara di Sopra 50, 40064 Ozzano dell'Emilia, BO, Italy
}

\begin{abstract}
A method previously developed for direct (non-enrichment) detection of Escherichia coli $\mathrm{O} 157: \mathrm{H} 7$ was adapted for Listeria monocytogenes. The sample treatment protocol was successful in concentrating bacteria from $10 \mathrm{~mL}$ raw milk samples and reducing PCR inhibition, but qPCR detection sensitivity and reproducibility was poor. Two DNA extraction reagents and multiple extraction conditions were tested to identify an efficient and reproducible DNA extraction method. Two primer/probe sets were evaluated at two concentrations and three annealing temperatures to minimize false-positive results and optimize sensitivity and reproducibility of qPCR detection. Under the selected conditions, DNA was extracted efficiently from the entire milk sample in a volume of $10 \mu \mathrm{L}$, and subsequently quantitated by a 5' nuclease qPCR assay lasting $50 \mathrm{~min}$. The method provided detection of $1 \mathrm{cfu} \mathrm{mL}^{-1}$ L. monocytogenes in $10 \mathrm{~mL}$ raw milk and quantitation from 10 to $1000 \mathrm{cfu} \mathrm{mL}^{-1}$ with a total time to result of $<3 \mathrm{~h}$.
\end{abstract}

\section{Introduction}

Outbreaks of foodborne illness associated with raw milk continue to occur at a significant rate in the US and Europe (De Buyser, Dufour, Maire, \& Lafarge, 2001; Langer et al., 2012). Rapid, quantitative detection methods with good sensitivity are important tools for preventing such outbreaks. Although enrichment methods have very low detection limits $\left(\sim 0.04 \mathrm{cfu} \mathrm{g}^{-1}\right)$, they provide only presence/absence information and exhibit long delays (1-4 days) between sampling and results. We previously described a method for the direct detection and quantitation of Escherichia coli $\mathrm{O} 157$ in raw whole milk samples that provided low detection limits $\left(\sim 1 \mathrm{cfu} \mathrm{mL} \mathrm{mL}^{-1}\right)$ without the use of toxic or flammable reagents in a total assay time of $\sim 3 \mathrm{~h}$ (Paul, Van Hekken, \& Brewster, 2013). Extension of this approach to other pathogens would provide a general method for rapid, sensitive quantitation of bacteria in raw milk.

Listeria monocytogenes was selected as the target for extension of the method due to its importance as a milk-borne pathogen. L. monocytogenes, Salmonella spp., and E. coli O157:H7 all occur with similar frequency (2.8-7.0\%) in bulk raw milk (Oliver, Boor, Murphy, \& Murinda, 2009), but L. monocytogenes exhibits a far higher mortality rate in infected individuals and is the only organism able to grow at refrigerator temperatures (Jay, Loessner, \& Golden, 2005). Cells of L. monocytogenes are significantly smaller than those of $E$. coli $\mathrm{O} 157: \mathrm{H} 7$ and potentially more difficult to recover by centrifugation. In addition, the rigid cell wall of $L$. monocytogenes and other Gram-positive organisms results in far less efficient DNA extraction than from the Gram-negative organisms such as E. coli (Brewster \& Paoli, 2013). We report here optimization of the DNA extraction and qPCR conditions and data demonstrating rapid detection and quantitation of L. monocytogenes. 


\section{Materials and methods}

\subsection{Bacterial cultures and enumeration}

L. monocytogenes ATCC 19115 (American Type Culture Collection, Manassas, VA, USA) was grown on Brain Heart Infusion Agar (BHIA) and stored at $4{ }^{\circ} \mathrm{C}$. Overnight $(16-20 \mathrm{~h})$ cultures were prepared by mixing a single colony with $3 \mathrm{~mL}$ of Brain Heart Infusion (BHI) broth and incubation at $37{ }^{\circ} \mathrm{C}$ with shaking at $250 \mathrm{rpm}$. Nominal bacteria concentrations were estimated from optical absorbance at $600 \mathrm{~nm}$ and actual concentrations determined by plating appropriate dilutions in $0.85 \%(\mathrm{w} / \mathrm{v}) \mathrm{NaCl}$ saline solution on BHIA plates.

\subsection{Milk sample treatment protocol}

Samples of raw bovine milk were purchased from local markets, kept at $4{ }^{\circ} \mathrm{C}$ and used before the sell-by date. The protocol used for preparation and treatment of spiked milk samples has been described previously (Paul et al., 2013). The same protocol was used here, apart from omission of diatomaceous earth as a pellet marker. Briefly, $10 \mathrm{~mL}$ milk was treated with EDTA and warmed to $35-40{ }^{\circ} \mathrm{C}$. L. monocytogenes dilutions $(20 \mu \mathrm{L})$ were added to the warmed milk, mixed, and centrifuged immediately ( $15 \mathrm{~min}, 4696 \times \mathrm{g}$ ). The fat and supernatant liquid were removed by aspiration, and the pellet containing bacteria was resuspended in lysis buffer containing SDS and treated with DNase I. After recovering the bacteria by centrifugation, the pellet was treated with trypsin, washed (saline solution $+0.1 \%$, w/v, Tween-20), and centrifuged to recover the bacteria.

\subsection{DNA extraction}

Extraction with $5 \mu \mathrm{L} 5 \times$ HotShot reagent followed the protocol described previously (Paul et al., 2013) with heating for 5-20 $\mathrm{min}$ at $65-95^{\circ} \mathrm{C}\left(5 \mathrm{~min}\right.$ at $95^{\circ} \mathrm{C}$ in the final protocol) followed by addition of $5 \mu \mathrm{L}$ neutralizer. Alternatively, $10 \mu \mathrm{L}$ of QuickExtract ${ }^{\mathrm{TM}}$ Bacterial DNA Extraction Solution $+0.1 \mu$ L Ready-Lyse Lysozyme Solution (Epicentre Biotechnologies, Madison, WI, USA) was added to $0.6 \mathrm{~mL}$ tubes containing $2 \mu \mathrm{L}$ samples. Samples were vortexed, incubated at room temperature for $15 \mathrm{~min}$, and heated to $80^{\circ} \mathrm{C}$ for $1-10 \mathrm{~min}$ as necessary. The full extract was added directly to PCR tubes for detection. Purified DNA was prepared with a commercial spin-column kit (DNeasy Blood and Tissue Kit, Qiagen, Valencia, CA, USA) and quantitated by UV spectrophotometry.

\subsection{Quantitative PCR assay}

Two 5' nuclease primer/probe sets were employed for detection of L. monocytogenes: one (hlyA-N) targeting an $113 \mathrm{bp}$ amplicon in the listerolysin $\mathrm{O}(h l y A)$ gene (Nogva, Rudi, Naterstad, Holck, \& Lillehaug, 2000) and the other (hlyA-R) targeting a second 63 bp amplicon in the hly $A$ gene (Rodríguez-Lazaro et al., 2004). Probe and primers for both sets were supplied as PrimeTime ${ }^{\circledR}$ assays (Integrated DNA Technologies, Coralville, IA, USA) containing 5 nmoles forward primer, 5 nmoles reverse primer, and 2.5 nmoles probe. Sequences of the hlyA-N set were forward primer: 5'-TGCAAGTCCTAAGACGCCA-3'; reverse primer: 5'-CACTGCATCTCCGTGGTATACTAA3'; and probe: FAM-5' CGATTTCATCCGCGTGTTTCTTTTCG-BkFQ. Sequences of the hlyA-R set were forward primer: 5'-CATGGCACCACCAGCATCT-3'; reverse primer: 5'ATCCGCGTGTTTCTTTTCGA-3'; and probe: FAM-5' CGCCTGCAAGTCCTAAGACGCCABkFQ. Reactions contained $10 \mu \mathrm{L}$ TaqMan Fast Advanced Master Mix (Applied Biosystems, Foster City, CA, USA), $1 \mu \mathrm{L}$ primer/probe and $9 \mu \mathrm{L}$ sample. A StepOne real time thermocycler (Applied Biosystems) was used with activation for $20 \mathrm{~s}$ at $95^{\circ} \mathrm{C}$, and 45 cycles of $1 \mathrm{~s}$ at $95^{\circ} \mathrm{C}$ and $20 \mathrm{~s}$ at $62{ }^{\circ} \mathrm{C}$. 
For optimization of PCR conditions, duplicate wells for each combination of primer/probe concentration $(500 / 250 \mathrm{nM}$ or $250 / 125 \mathrm{nM})$ and annealing temperature contained purified DNA at $1,10,100$, and $1000 \mathrm{pg}$. Reaction (amplification) efficiency was calculated with the thermocycler software package. For assays of raw milk, samples were inoculated in triplicate with $0,1,10$, and

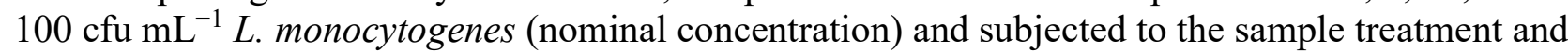
DNA extraction protocols above. DNA extracts were assayed by qPCR using the hlyA-N primer/probe set at $250 / 125 \mathrm{nM}$ with $62^{\circ} \mathrm{C}$ annealing temperature. The assay included triplicate positive (purified DNA) and negative (water) controls.

\section{Table 1}

Effects of hlyA-N and hlyA-R primer concentration and annealing temperature on $\mathrm{C}_{\mathrm{T}}$ values with 1 pg DNA of L. monocytogenes.

\begin{tabular}{llllll}
\hline Primer set Primer $(\mathbf{n M})$ & Annealing $\left({ }^{\circ} \mathbf{C}\right)$ & $\mathbf{C}_{\mathrm{T}}$ mean & $\mathbf{C}_{\mathrm{T}} \boldsymbol{\sigma}$ & Efficiency $(\%)$ \\
\hline hlyA-N & 500 & 60 & 29.4 & 0.015 & 99 \\
& 250 & 60 & 31.7 & 0.044 & 91 \\
& 500 & 62 & 29.2 & 0.004 & 101 \\
& 250 & 62 & 30.7 & 0.086 & 94 \\
& 500 & 64 & 28.7 & 0.178 & 97 \\
hlyA-R & 250 & 64 & 30.8 & 0.136 & 89 \\
& 500 & 63 & 28.7 & 0.006 & 85 \\
& 250 & 63 & 29.7 & 0.022 & 95 \\
& 500 & 65 & 29.1 & 0.127 & 82 \\
& 250 & 65 & 31.2 & 0.019 & 90 \\
& 500 & 67 & 33.0 & 0.002 & 58 \\
& 250 & 67 & 39.3 & 0.366 & 69 \\
\hline
\end{tabular}

\section{Results and discussion}

\subsection{PCR assay optimization}

There are many primer-probe combinations available for qPCR assays of L. monocytogenes (Dadkhah et al., 2012; Klein \& Juneja, 1997; Rantsiou, Alessandria, Urso, Dolci, \& Cocolin, 2008). We selected two qPCR primer/probe sets for investigation based on reported high selectivity, sensitivity and inclusivity for L. monocytogenes strains: hlyA-N (Barbau-Piednoir, Botteldoorn, Yde, Mahillon, \& Roosens, 2013; Nogva et al., 2000) and hlyA-R (Rodríguez-Lazaro et al., 2004). Preliminary experiments (data not shown) using PrimeTime ${ }^{\circledR}$ primer/probe sets at the manufacturer's recommended concentrations $(500 / 250 \mathrm{nM})$ and literature annealing temperatures exhibited issues with false-positives, reproducibility, and sensitivity in blank milk samples. Experiments were conducted to identify primer/probe concentrations and annealing temperatures that would provide improved performance. Table 1 details $C_{T}$ values for $1 \mathrm{pg}$ DNA and efficiency calculated from the entire range (1-1000 pg) of DNA tested. For both primer/probe sets, $\mathrm{C}_{\mathrm{T}}$ values increased as annealing temperature was raised and as primer concentration was lowered. However, the hlyA-N primer/probe exhibited less variation in $\mathrm{C}_{\mathrm{T}}$ and efficiency than hlyA-R, and this more robust primer set was chosen for subsequent experiments. The combination of $250 \mathrm{nM}$ hlyA-N primer and $62{ }^{\circ} \mathrm{C}$ annealing temperature was selected for further work as it was expected to produce fewer false-positives than $500 \mathrm{nM}$ primer while providing good sensitivity and high efficiency.

\subsection{Comparison of DNA extraction techniques}


Previous research (Brewster \& Paoli, 2013) indicated that QuickExtract ${ }^{\mathrm{TM}}$ (QEX) and HotShot (Truett et al., 2000) were the most effective reagents for direct DNA extraction from L. monocytogenes, providing relatively high recovery and minimal PCR inhibition. The QuickExtract ${ }^{\mathrm{TM}}$ protocol calls for a $15 \mathrm{~min}$ incubation of the cells with the reagent at room temperature. The optional $2 \mathrm{~min}$ heating step at $80{ }^{\circ} \mathrm{C}$ to kill viable bacteria was not tested in the previous study. Table 2 shows qPCR assay results (500/250 nM hlyA-N primer/probe concentration) after treatment of $500 \mathrm{cfu}$ samples of L. monocytogenes with QuickExtract ${ }^{\mathrm{TM}}$. Heating at $80^{\circ} \mathrm{C}$ significantly improved recovery (evidenced by reduced $\mathrm{C}_{\mathrm{T}}$ value), with optimal results obtained with heating for $2 \mathrm{~min}$. Preliminary experiments with the $2 \times$ HotShot reagent used previously in detection of $E$. coli (Paul et al., 2013) indicated poor recovery of L. monocytogenes DNA (data not shown). Results of experiments with $5 \times$ HotShot under a variety of conditions are shown in Table 3 . Heating for $5 \mathrm{~min}$ at $95{ }^{\circ} \mathrm{C}$ gave low, reproducible $\mathrm{C}_{\mathrm{T}}$ values $(28.6 \pm 0.3)$. Under these qPCR conditions (250/125 nM hlyA-N primer/probe concentration) samples extracted with QuickExtract ${ }^{\mathrm{TM}}$ with 2-min heating at $80^{\circ} \mathrm{C}$ gave $\mathrm{C}_{\mathrm{T}}$ values of $35.1 \pm 1.5$.

\section{Table 2}

DNA extraction of $500 \mathrm{cfu}$ L. monocytogenes with QuickExtract ${ }^{\mathrm{TM}}$ : effect of heating on $\mathrm{C}_{\mathrm{T}}{ }^{\mathrm{a}}$

\begin{tabular}{lll}
\hline Heating time (min) & $\mathbf{C}_{\mathrm{T}}$ mean & $\mathbf{C}_{\mathrm{T}} \boldsymbol{\sigma}$ \\
\hline 0 & 33.5 & 0.4 \\
1 & 30.5 & 1.0 \\
2 & 29.9 & 0.4 \\
4 & 30.7 & 0.7
\end{tabular}

${ }^{\text {a }}$ Samples were mixed with reagent, incubated $15 \mathrm{~min}$ at room temperature, then heated at $80{ }^{\circ} \mathrm{C}$; hlyA-N primer/probe: 500/250 nM.

\section{Table 3}

DNA extraction of $500 \mathrm{cfu}$ L. monocytogenes with $5 \times$ HotShot: effect of heating on $\mathrm{C}_{\mathrm{T}}{ }^{\text {a }}$

\begin{tabular}{llll}
\hline Temperature $\left({ }^{\circ} \mathbf{C}\right)$ & Time $(\mathbf{m i n})$ & $\mathbf{C}_{\mathrm{T}}$ mean & $\mathbf{C}_{\mathrm{T}} \boldsymbol{\sigma}$ \\
\hline 65 & 10 & 30.7 & 0.5 \\
65 & 20 & 29.2 & 1.0 \\
75 & 10 & 28.4 & 0.4 \\
85 & 10 & 28.2 & 0.3 \\
95 & 5 & 28.6 & 0.3 \\
\hline
\end{tabular}

${ }^{\text {a }}$ Samples were heated with $5 \mu \mathrm{L}$ reagent, then mixed with $5 \mu \mathrm{L}$ neutralizer; hlyA-N primer/probe: 250/125 nM.

\section{3. $q P C R$ assay performance}

140 DNA was extracted by the method protocol from samples of bacterial cells suspended in saline 141 solution or samples of raw milk that were inoculated just prior to DNA extraction. Results for 142 triplicate samples of both types with various levels of bacteria are shown in Fig. 1. The $\mathrm{C}_{\mathrm{T}}$ values 143 were unaffected by the presence of milk, indicating efficient removal of inhibitors during sample 144 processing and extraction. Fewer than $10 \mathrm{cfu}$ per reaction were detected (corresponding to

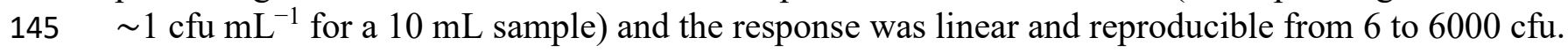




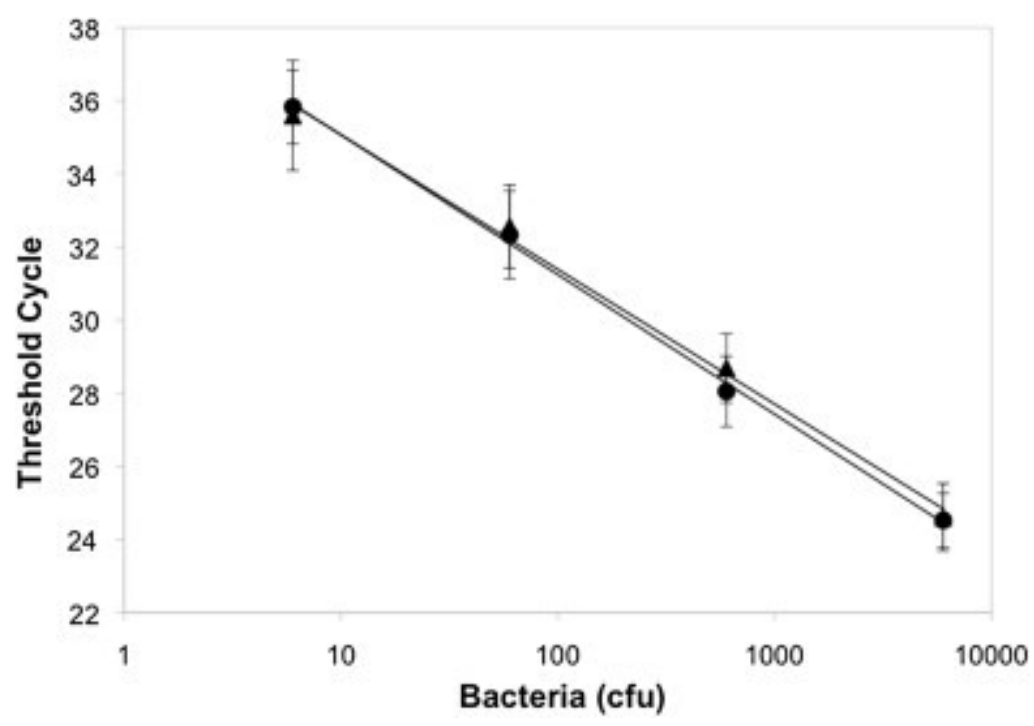

Fig. 1. qPCR results for L. monocytogenes in saline and in treated milk. Each qPCR reaction contained the indicated amount of bacteria. Symbols ( $\bullet$, cells in the presence of milk; $\mathbf{\Delta}$, cells in saline solution) represent the mean and error bars represent the standard deviation for triplicate samples; the solid line represents a logarithmic fit to the data points.

\subsection{Application}

Sensitivity and reproducibility were studied using $10 \mathrm{~mL}$ raw milk samples inoculated at $0,1,10$, and $100 \mathrm{cfu} \mathrm{mL}^{-1}$ (nominal concentration). The results from five experiments over three days in Table 4 showed detection of $1 \mathrm{cfu} \mathrm{mL}^{-1}$, although one replicate failed to amplify at this level in three trials. No amplification of the negative controls was observed, and one false-positive result (amplification before 40 cycles) was observed in one replicate of the blank milk ( $0 \mathrm{cfu})$ sample. Quantitation, within-day and day-to-day reproducibility were considered to be acceptable.

\section{Table 4}

Reproducibility of threshold cycle $\left(\mathrm{C}_{\mathrm{T}}\right)$ values for raw bovine milk spiked with low levels of L. monocytogenes. ${ }^{\mathrm{a}}$

\begin{tabular}{|c|c|c|c|c|c|c|c|c|c|c|}
\hline \multirow{2}{*}{$\begin{array}{l}\text { Spike level } \\
\left.\text { (cfu } \mathrm{mL}^{-1}\right)\end{array}$} & \multicolumn{2}{|c|}{ Trial 1} & \multicolumn{2}{|c|}{ Trial 2} & \multicolumn{2}{|c|}{ Trial 3} & \multicolumn{2}{|l|}{ Trial 4} & \multicolumn{2}{|c|}{ Trial 5} \\
\hline & Mean & $\sigma$ & Mean & $\sigma$ & Mean & $\sigma$ & Mean & $\sigma$ & Mean & $\sigma$ \\
\hline 0 & $\mathrm{U}$ & - & $\mathrm{U}$ & - & $\mathrm{U}$ & - & $38.9^{b}$ & - & $\mathrm{U}$ & - \\
\hline 1 & $39.5^{\mathrm{c}}$ & 0.01 & $38.1^{\mathrm{c}}$ & 2.2 & 38.4 & 0.6 & 37.3 & 0.8 & $38.1^{\mathrm{c}}$ & 1.3 \\
\hline 10 & 34.9 & 0.3 & 35.4 & 0.7 & 35.6 & 2.1 & 35.2 & 0.7 & 33.5 & 0.5 \\
\hline 100 & $32.6^{\mathrm{c}}$ & 0.2 & 32.8 & 1.9 & 32.5 & 2.5 & 32.1 & 0.5 & 31.2 & 0.4 \\
\hline $\mathrm{PC}$ & 27.6 & 0.1 & 27.1 & 0.1 & 27.1 & 0.1 & 27.3 & 0.2 & 28.1 & 0.4 \\
\hline
\end{tabular}

${ }^{\mathrm{a}} \mathrm{U}$, no amplification within 40 cycles; PC, positive control (10 pg purified DNA).

${ }^{\mathrm{b}}$ One of three replicate samples exhibited PCR amplification.

${ }^{c}$ Two of three replicate samples exhibited PCR amplification.

\section{Conclusions}

The sample treatment steps previously reported for detection of E. coli $\mathrm{O} 157: \mathrm{H} 7$ were combined with modified DNA extraction and qPCR steps to provide an assay for L. monocytogenes with comparable sensitivity and $15 \mathrm{~min}$ shorter time to results. The method accommodates relatively large $(10 \mathrm{~mL})$ samples and produces data from a set of 12 samples in less than $3 \mathrm{~h}$, including qPCR. L. monocytogenes could be detected at $1 \mathrm{cfu} \mathrm{mL}^{-1}$ and quantified from 10 to $1000 \mathrm{cfu} \mathrm{mL}^{-1}$, although the precision of the L. monocytogenes assay was somewhat lower than that for E. coli 
O157:H7. The successful detection of both Gram-negative and Gram-positive bacteria with this approach indicates its potential for application to other bacteria in raw milk.

\section{Acknowledgement}

The authors would like to acknowledge Ms. Ly Nguyen (USDA-ARS-NAA-ERRC) for technical assistance.

\section{References}

Barbau-Piednoir, E., Botteldoorn, N., Yde, M., Mahillon, J., \& Roosens, N.H. (2013).

Development and validation of qualitative $\mathrm{SYBR}^{\circledR}$ Green Real-Time PCR for detection and discrimination of Listeria spp. and Listeria monocytogenes.

Applied Microbiology and Biotechnology, 97, 4021-4037.

Brewster, J.D., \& Paoli, G.C. (2013).

DNA extraction protocol for rapid PCR detection of pathogenic bacteria.

Analytical Biochemistry, 442, 107-109.

Dadkhah, H., Bassami, M.R., Hashemi, S., Shahraz, F., Hosseini, H., Karatzas, K.A.G., et al. (2012).

Evaluation and comparison of SYBR Green I Real-Time PCR and TaqMan Real-Time PCR methods for quantitative assay of Listeria monocytogenes in nutrient broth and milk. African Journal of Microbiology Research, 6, 1908-1917.

De Buyser, M.L., Dufour, B., Maire, M., \& Lafarge, V. (2001).

Implication of milk and milk products in food-borne diseases in France and in different industrialised countries.

International Journal of Food Microbiology, 67, 1-17.

Jay, J.M., Loessner, M.M., \& Golden, D.A. (2005).

Modern food microbiology (7th ed.).

New York, NY, USA: Springer Science and Business Media, Inc. Chapt. 25.

Klein, P.G., \& Juneja, V.K. (1997).

Sensitive detection of viable Listeria monocytogenes by reverse transcription-PCR.

Applied and Environmental Microbiology, 63, 4441-4448.

Langer, A.J., Ayers, T., Grass, J., Lynch, M., Angulo, F.J., \& Mahon, B.E. (2012).

Nonpasteurized dairy products, disease outbreaks, and state laws-United States, 1993-2006.

Emerging Infectious Diseases, 18, 385-391.

Nogva,, H.K., Rudi, K., Naterstad, K., Holck, A., \& Lillehaug, D. (2000).

Application of 5'-nuclease PCR for quantitative detection of Listeria monocytogenes in pure cultures, water, skim milk, and unpasteurized whole milk.

Applied and Environmental Microbiology, 66, 4266-4271.

Oliver, S.P., Boor, K.J., Murphy, S.C., \& Murinda, S.E. (2009).

Food safety hazards associated with consumption of raw milk.

Foodborne Pathogens and Disease, 6, 793-806.

Paul, M., Van Hekken, D.L., \& Brewster, J.D. (2013).

Detection and quantitation of Escherichia coli $\mathrm{O} 157$ in raw milk by direct qPCR.

International Dairy Journal, 32, 53-60.

Rantsiou, K., Alessandria, V., Urso, R., Dolci, P., \& Cocolin, L. (2008).

Detection, quantification and vitality of Listeria monocytogenes in food as determined by quantitative PCR.

International Journal of Food Microbiology, 121, 99-105.

Rodríguez-Lazaro, D., Hernandez, M., Scortti, M., Esteve, T., Vazquez-Boland, J.A., \& Pla, M. (2004). 
Quantitative detection of Listeria monocytogenes and Listeria innocua by real-time PCR: assessment of hly, iap, and lin02483 targets and AmpliFluor technology. Applied and Environmental Microbiology, 70, 1366-1377.

Truett, G.E., Heeger, P., Mynatt, R.L., Truett, A.A., Walker, J.A., \& Warma, M.L. (2000). Preparation of PCR-quality mouse genomic DNA with hot sodium hydroxide and Tris (HotSHOT). BioTechniques, 29, 52-54. 